\title{
The role of English in the language practices of Mongolian Facebook users
}

\author{
SENDER DOVCHIN
}

English meets Mongolian on social media

\section{Introduction}

Drawing on the linguistic practices of Facebook (FB) users in Mongolia, this article illustrates how multiple local meanings are produced in the local context of Mongolia, while English oriented linguistic resources are assimilated and injected into the local language - Mongolian. The research is timely in the context of contemporary Mongolia, as English continues to spread over and is used in more diverse ways than ever. Before 1990, Mongolia was a socialist nation, the satellite of the Soviet Union, with Russian language being the most important foreign language. English and other Western languages were uncommon, and Western cultural elements were largely resisted (Marsh, 2010). Following the collapse of Soviet Union, Mongolia embraced a new democratic society in 1990, transforming itself from a socialist to a democratic country with free market economy. Mongolia embraced the linguistic and cultural diversity, and English and other foreign languages have replaced the once popular Russian language. English has now immense role in both institutional and non-institutional contexts (Dovchin, 2016a, 2016b).

In particular, due to enhanced urbanization and increased access to diverse new media and technologies, English has become one of the inextricable sociolinguistic realities for daily lives of urban Mongolians. New social media sites are particularly caught up in this transition, where English is constantly mixed and interlaced with the Mongolian language (Dovchin, 2011, 2015). Today, considering the relatively small population (about 3 million), the statistic report of Internet World Statistics (2016) shows that there are more than 1,300,000 Internet users in Mongolia. Social media like Facebook has specifically soared in popularity, with more than half a million FB users.

Within this impressive online social network, the linguistic bricolage of English and Mongolian that appears on the thousands of online pages and websites is often treated as the same English that is taught in the EFL classrooms. While a great deal of concern has been expressed about the role of English in institutional contexts in Mongolia since 1990 (Cohen, 2005), there has been less focus on the non-institutional role of English in Mongolia. English seems to appear with tremendous frequency in the form of English-Mongolian mixing in the online settings, while it is typically treated as ideologically and linguistically separate

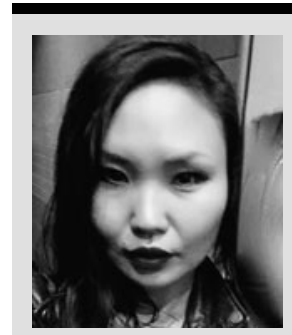

SENDER DOVCHIN is a Postdoctorate Associate at the Faculty of Arts and Social Sciences, University of Technology, Sydney. She completed her PhD degree in language education, and $M A$ degree in TESOL at the University of Technology, Sydney. Her research interests include sociolinguistic diversity in globalization, including language and identity in post-Soviet nations. She has authored articles in international peer-reviewed journals, such as Journal of Sociolinguistics, International Journal of Multilingualism, World Englishes, Asian Englishes, Translanguaging and Translation in Multilingual Contexts and Inner Asia. Email: Sender.Dovchin@ uts.edu.au 
from Mongolian by the majority of language educators in Mongolia.

This is a problem because the informal function of English in a particular society is important part of understanding the overall role and impact of English (Preisler, 1999). The online linguistic practices of Mongolians are rapidly evolving due to current globalization, which impacts on overall sociolinguistic practices. They need to be considerably addressed within current language educational settings. We, as language educators, need to grasp the implications of a growing need to investigate the new conditions and ways of English being integrated into the local society (Dovchin, 2016b).

This article thus seeks to understand the noninstitutional role of English in the local society, avoiding dominant conceptualizations of English either as a distinct code or as a global language. The article addresses two main questions:

1. To what extent and how is English used in the language practices of Facebook users in Mongolia?

2. What happens to the Mongolian language as a result?

\section{English as a local language practice}

Some scholars interested in the role of English mixing in the local context in late modernity have started to question whether the conventional categorizations of linguistic mixing such as 'codeswitching' really work any more in understanding the real life English use of modern people (Otsuji \& Pennycook, 2010; Jørgensen et al., 2011; Canagarajah, 2013). As noted elsewhere, codeswitching is a common knowledge in which two separate language systems are used in daily interaction (Myers-Scotton, 2006). Codeswitching essentially refers to the linguistic switching and mixing by bi/multilinguals of two or more languages in discourse (Poplack, 2001; GardnerChloros, 2009).

From the initial glimpse, it is probably common to find dialogues such as codeswitching where speakers switch between two or more languages. What might cause us to hesitate, however, as Otsuji \& Pennycook (2011: 241) acknowledge, is that the so-called codeswitching dialogues might 'derive not so much from the use of different first and second languages' but rather as the result of mixed linguistic codes becoming the lingua franca of people's communication. In a similar vein, Jørgensen (2008) suggests that it is far less relevant when it comes to investigating mixed language practices from the perspective of code-switching, because the speakers seem to display the signs that they are not essentially proficient or at least skilled only to a limited degree in the various languages they borrow or switch. Sultana, Dovchin \& Pennycook (2013: 700) highlight that instead of examining the mixed language practices of modern speakers in terms of 'codeswitching' 'with a concomitant assumption about distinct codes being switched or mixed', it is far more relevant to view this type of mixture as the 'integrated forms of stylization', since these speakers are involved within the combination of various cultural modes, styles and genres.

The use of English in the local context is no exception. For Higgins (2009: 2), 'English is a component of "urban vernaculars", or ways of using language that are better described as amalgams rather than as codeswitches between languages'. English needs to be seen as part of local language practice. In order to understand how hybridized English is interpreted in the local context, Higgins (2009) reconceptualises English as a social everyday practice that is constantly being reconstructed in a specific locality. English can serve a local sphere through creatively mixing varied genres and resources, which means the localized English may involve more than just English. Out of this mix, new locally relevant meaning and language may occur.

Similarly, Canagarajah (2005: 439-440) notes that the use of English [in post-colonial communities] is not unconditional, 'It is clear that the [Sri Lankan Tamil] community is using English on its own terms. The pervasive code-switching suggests that English is made impure through mixing with Tamil. Tamils are accommodating English in a way that it will fit into their ethos. In other words, they are vernacularizing - or Tamilizing English!' Most recently, Canagarajah (2013) acknowledges that English mixing is about how individuals mobilize different semiotic resources and adopt different negotiation strategies to make local meanings across linguistic boundaries rather than focusing on fixed grammar, forms, and discrete language systems.

Likewise, for Blommaert (2010: 79), English is also viewed as 'translocal' since different forms of locality are transported into other contexts of locality such that these "localities do not necessarily become more "global" or "deterritorialized" because of such patterns of translocalization'. In short, 'meanings are primarily imported into local systems of meaningfulness' and 'they remain as 
local as before' (Blommaert, 2010: 79). Schneider (2007: 1) also acknowledges that English has widely diversified, developing into homegrown local forms and used in multiple locations. In many contexts, English has become a local and indigenized language, where indigenous population adopt and appropriate the English language for themselves, 'thus contributing to its diversification and the emergence of new varieties' (Schneider, 2007: 1).

Pennycook (2010) notes that we need to consider what language users do with English, how they use it to their own condition and what new meanings are generated by this use. The common portrayals of English as having spread around the world as the language of a globalizing world inadequately portray an understanding of what is already local. It is thus far more dynamic to understand English through how it transforms into the question of what it means to be local. For Pennycook (2010: 35-37), the notion of 'relocalization' is essential in understanding the language use in terms of 'fertile mimesis', a form of language repetition that creates difference. Relocalization of English hence is not understood as a repetition of the same thing, but of repetition as an act of renewal and revitalization. English is localized differently each time, and create a new or local meaning in which they happen.

From this point of view, this article will look at the role of English in the Mongolian Facebook users through how the speakers localize available resources and further make new or locally relevant meanings out of that context. That is to say, the role of English in the local context is understood, following Dovchin et al. (2015), not only through how the speakers borrow, repeat and mimic English but also through the ways they make local linguistic meanings within this complex relocalizing process (see also Dovchin, 2016a, 2016b). As Leppänen et al. (2009: 1081) suggest, 'The skilled use of the new media together with the use of English form a powerful combination providing local actors access to translocal activity spaces and communities of practice where young [people] can create discourse that is appropriate and meaningful within their particular contexts and normative frameworks.'

\section{Linguistic netnography}

The data examples used in this article derive from a larger longitudinal 'netnographic study' (Kozinets, 2002, 2015) - an ethnographic qualitative research methodology, which specifically looks at the linguistic behavior of online users. This method gives the researcher an opportunity to observe the participants' digital and online behaviour, employing a natural and unobtrusive manner (Kozinets, 2002). Through netnography, the researcher participates in the online environment while observing and taking notes of what is culturally and linguistically happening in the particular online space (Dovchin, 2015). One of the most important methods incorporated within netnography is a prolonged engagement, persistent observation and vigilance when the researcher is online (Kozinets, 2015).

Through netnography, I looked into the linguistic behaviors of Mongolians on the social networking website Facebook, starting from July 2011 until December 2015, focusing on the Facebook posts of 24 public community pages. For the purpose of the present article, I will introduce four Facebook public pages that are completely open to public access. Following McCorkindale's (2010) research method to deal with FB data, only public FB pages were selected for this research due to ethical issues, while 'closed' or 'restricted' FB pages were not qualified. Following Battles's (2010: 35) reference to the Internet based public groups and message boards - 'publicly available, unsolicited information' - FB public pages became one of the most useful online sites to engage with the Mongolian Internet users in 'real time'.

I have particularly selected four extracts for the data presentation section from the hundreds of pages of data that the netnography has yielded, with the primary aim of introducing a range of English resources that FB users make use in their mixed language practices. These examples, however, cannot fully represent the role of English across all FB users in Mongolia in general, as the research has been restricted to only limited number of FB public pages. FB profile names of all users retrieved in these extracts are pseudonyms, and FB profile picture windows were all removed to protect anonymity. All the administrators of these FB public pages were contacted to get the permission and consent of reproducing their materials. Linguistic examples presented in the article followed the Leipzig Glossing Rules.

\section{The Localization of English in the Mongolian language}

Four extracts presented in this section are categorized on the basis of the dominant stylistic and linguistic representation of English embedded within Mongolian language and are presented in 
following sections titled as 'Anglicised gastronomic Mongolian', 'Anglicised sporty Mongolian', 'Anglicised filmic Mongolian' and 'Anglicised tech Mongolian'.

\section{Anglicized gastronomic Mongolian}

In Extract 1, a food-related Mongolian FB public page - 'Khorkhoi Odnoo Kitchen' (2015) - is used to present the ways in which English is mixed with the Mongolian language, creating further locally relevant meanings. This page is an open public page of Odnoo, a celebrity Mongolian chef, who posts varied videos and photos of cooking various sophisticated meals. She has overall ' $63 \mathrm{k}$ ' followers in her page, and is often seen to be directly interacting with her FB followers.

In Extract 1, English has been localized in varied ways within the popular online orthographic choice for many digital users in Mongolia - the transliterated Roman Mongolian script:

- In lines 1 and 3, the original English term 'brie cheese' is used throughout the conversation, since there is no appropriate Mongolian equivalent for English 'brie cheese'. In line 3, 'brie cheese' is Mongolianized through the addition of Mongolian suffix '-e'〈'your'〉, creating the new local linguistic term 'brie cheesee' 〈'your brie cheese' $\rangle$.
- In line 2, English root terms such as 'salad' and 'jam' are added into the Mongolian question sentence. The term 'salad' is often not translated into the Mongolian language and used as it is. However, a Mongolian term, 'jam bgaa' 〈'to have jam' $\rangle$, is created through the integration of English 'jam' with the Mongolian verb 'bgaa' 〈'to have', , a shortened version of the Mongolian 'baigaa' by omitting the middle vowels 'ai'. Note that using the shortened versions of varied terms through omitting the vowels or consonants is a common online practice in Mongolia (Dovchin et al., 2016; Sultana et al., 2015).

- In line 3, a new Mongolian phrase - 'bread crumbs unhuruuleed' ' 'is mixed in the bread crumbs' $\rangle$ is produced by the chef, through the combination of English 'bread crumbs' with the Mongolian verb 'unhuruuleed' ' 'is mixed in the' $\rangle$. Note also that English words 'brie cheese' and 'bread crumbs' are incorporated into the Mongolian sentence in accordance with the Mongolian grammatical and syntax structure. Overall, Odnoo is in fact writing the Mongolian sentence despite her usage of English terms. The Mongolian sentence is sort of modified and adjusted through the assimilation of English gastronomic terms, where they have been correspondingly localized and used as part of Mongolian language.

\section{Extract 1}

\section{Facebook text}

Altan:

1. Brie cheese sharsan yum uu?

Brie cheese fried did you?

'Did you fry the brie cheese?'

2. Tegeed salad, tomor aygand ni jam bgaa yum uu?

And salad, steel bowel inside the jam to have there is?

'And is there jam inside the salad and the steel bowl?'

Like $\cdot$ Reply $\cdot 1$ July at 23:14

Khorkhoi Odnoo Kitchen:

3. Brie cheesee bread crumbs unhuruuleed tegeed sharna

Brie your cheese bread crumbs is mixed and then is fried

'Your brie cheese is mixed in the bread crumbs and then fried'

Like $\cdot$ Reply $\cdot 1$ July at 23:20 


\section{Anglicized sporty Mongolian}

The examples presented in Extract 2 are retrieved from the FB public page of Mongolian Ski Association (2015). The page has 690 members and is mainly hosted by the Mongolian language. Leppänen et al. (2009: 1099) suggest that the online community members in a Finnish sports discussion forum tend to inject English elements into Finnish (and vice-versa), borrowing from English extreme sports jargon, producing integrative and unconventional forms of Finnish. This practice has become a part of their daily linguistic repertoires, as they seem 'to expect familiarity with it when interacting with each other' (Leppänen et al., 2009: 1099). For these online members, two separate codes 'English' and 'Finnish' is perceived as one, because it is simply how they talk. In a similar vein to these Finnish examples, many English sports jargons are localized in the Mongolian language in this FB page. For example:

- In lines 1 and 2, the name of popular cable TV station in Mongolia, 'UNIVISION' is combined with the Anglicized Mongolian 'видео' 〈'video'〉 and the Mongolian word 'санд' 〈'in the collection' $\rangle$, creating the Mongolian term, 'UNIVISION видео санд', meaning 'in the video collection of UNIVISION'.

- In line 3, English term, 'snowboarders', is localized through the Cyrillic Mongolian as 'Сноубордчин', combining the English stem 'snowboard' and the Mongolian suffix '-чин' $\langle$ '-er', , which indicates a person having a particular job. There is no equivalent Mongolian translation for 'snowboarders' in Mongolia, and hence the snowboarding fans in Mongolia opt for the Anglicized Mongolian version 'Сноубордчин'.

- In line 4, the English root term 'cross-country skiers' is Mongolianized through mixing the English term 'cross-country' with the Mongolian 'tsanachid' 〈'skiers'〉, producing the local term - 'cross-country tsanachid' $\langle$ 'cross-country skiers' $\rangle$. Just like 'snowboarders', there is no exact Mongolian translation for 'cross-country', and the sports fans tend to localize English origin 'cross-country' in the local language through combining it with the Mongolian linguistic resources.

\footnotetext{
Extract 2

Facebook text

Mongolian Ski Association:

1. 3 а удаан хүлээлгэсэн кино маань UNIVISION видео OK long awaited movie our UNIVISION video

2. санд тавигдлаа.

in the collection has been added.

'OK, our long awaited movie has been added in the UNIVISION video

collection.'

3. Сноубордчин залуусынхаа энэхҮY киног таалан Үзээрэй (-)

Snowboarders youth this movie enjoy watch please

'Please enjoy watching this movie about the young snowboarders'

Like $\cdot$ Reply $\cdot 27$ July 2015

4. cross-country tsanachid zunii beltgelee

cross-country skiers summer's their training

5. Bulgan aimgiin Unitad bazaaj bn

Bulgan province's in Unita doing are

'Cross-country skiers are doing their summer training in Unita, Bulgan province'

Like $\cdot$ Reply $\cdot 26$ July 2015
} 


\section{Anglicized filmic Mongolian}

Extract 3 will look at the public FB movie fan page 'Kinood' (2015) with over '200k likes'. The members of this FB page discuss about their favorite movies and inform each other about new movie trailers. English has been localized in varied ways in this example:

- In line 1 , the title of American 3D computeranimated comedy film, Minions, and its main characters - small and yellow creatures, called 'Minions', is relocalized by the Mongolian FB users as 'Минионууд' 〈'Minions'〉. English 'Minion' is Cyrillically Mongolianized as 'Минион', while its plural '〈'Minions'〉-s' is localized through the incorporation of the Mongolian plural indicator suffix '-ууд' 〈'-s' $\rangle$. In a similar vein, the name of hive-minded alien race called the Boov $\langle\mathrm{s}\rangle$, the main characters of American 3D computer-animated comedy film, Home, is relocalized by the Mongolian FB users as 'Бүүвүүдийн' ('The Boovs' $\rangle$. English 'Boov' is Cyrillically Mongolianized as 'БүҮв', while its plural ' $\langle$ 'Boov' $\rangle$-s' is assimilated into the Mongolian plural indicator suffix '-үүдийн' $\langle$ '-s' $\rangle$, creating a new Mongolian term 'Бүүвүүдийн'.

- In lines 2 and 3, English is localized through recycling the English movie title 'Transformers: Revenge of the fallen' in the transliterated Roman Mongolian sentence. Note that the English movie title is serving as the main subject of the Mongolian sentence. Munkh also integrates English greeting 'Hi' and the polite English, 'thx' - a shortened version of English 'thanks'. These short English greetings such as 'hi', 'bye', 'hey' or the polite English expressions such as 'thanks' and 'please' are widely used across Mongolian offline and online speakers. Online users often opt for the shortened versions as it is much more convenient to use these shortened versions such as 'hi' or 'thx' instead of long Mongolian version such as 'Sain baina uu' or 'Bayarlalaa'.

\section{Anglicized tech Mongolian}

In Extract 4, the examples retrieved from the Mongolian FB online shop 'Тунгалаг дурангийн дэлгүүр' ‘'The Shop of transparent lens'〉 (2015) is presented in order to show how English 'technology-oriented' terms are localized by the Mongolian FB users. This online FB shop has over 50k members, and it sells telescopes, binoculars, spotting scopes, microscopes, and accessories imported from the American Celestron company. The page also hosts a wide variety of online promotions and events amongst their members to advertise their products.

The presence of English is popular across this FB online shop. However, English is localized and used as part of Mongolian language rather than functioning as the separate linguistic code. For example, the page uploads a promotion video

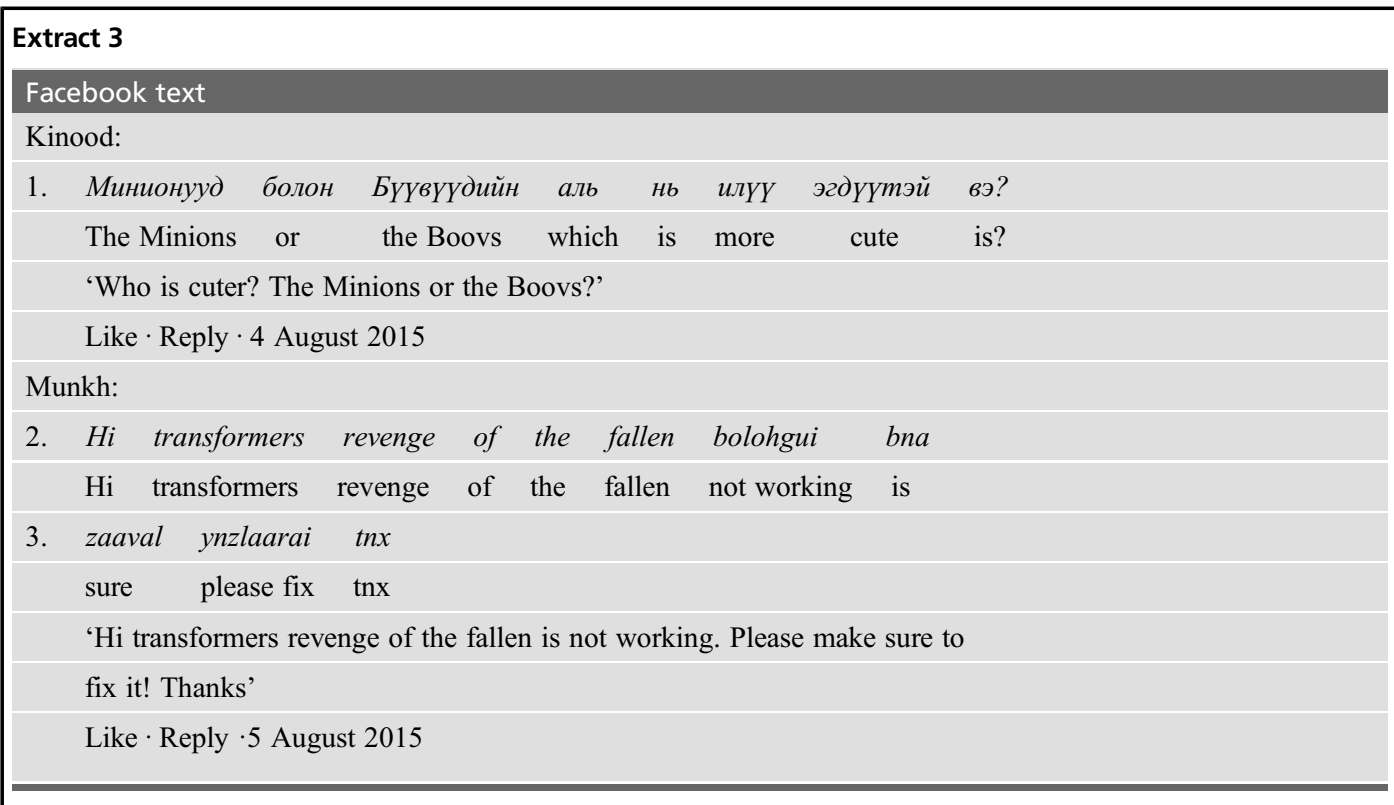




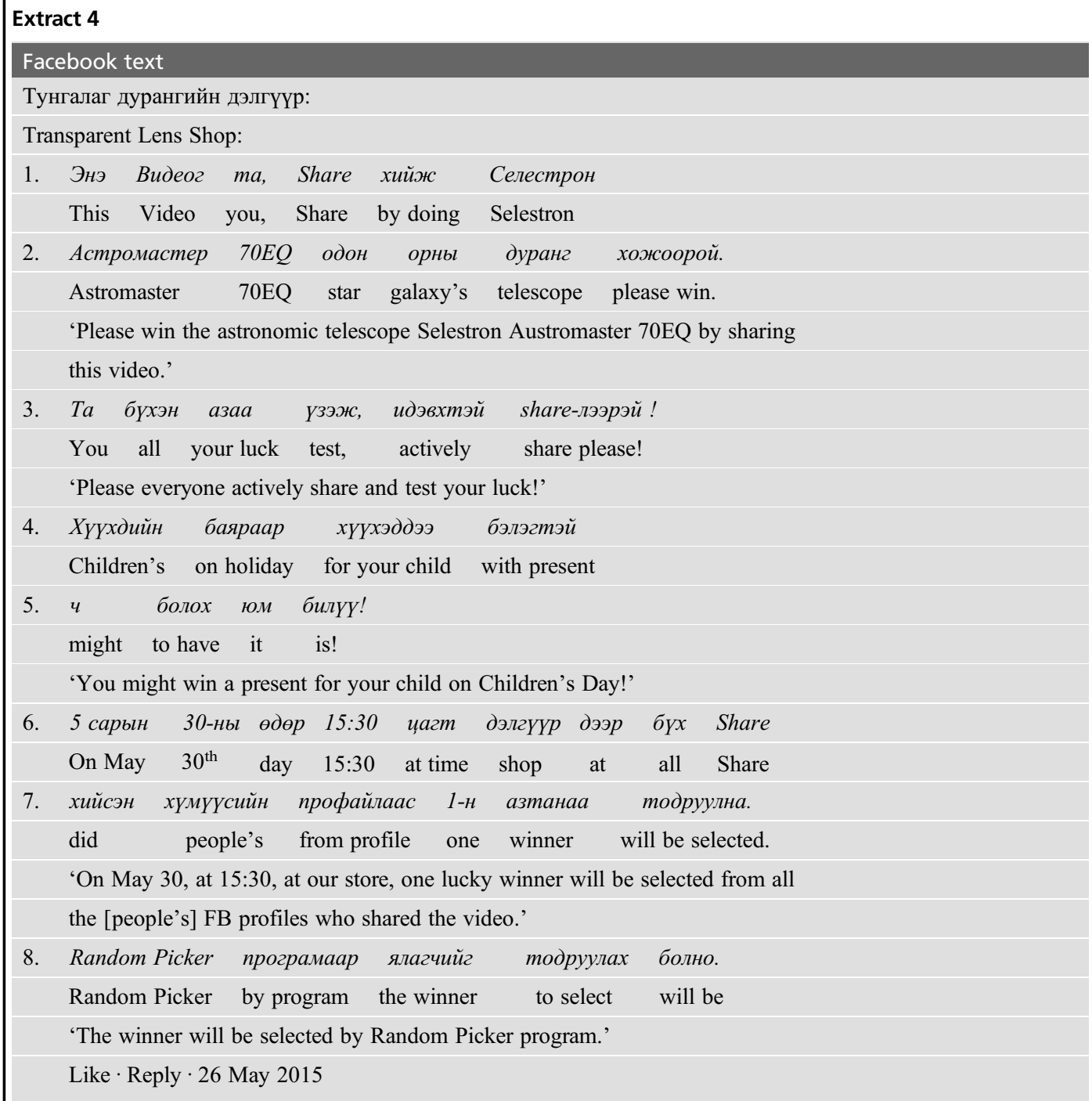

within their FB page (line 1) in order to advertise one of their latest astronomical telescopes. The page asks its members to share the video on their own FB pages, and one of the lucky members is supposed to be selected as the winner of this magnificent telescope.

One of the most repetitively used English stem word is 'share' in this promotion. Yet, 'share' has always been localized and makes a valid meaning only in conjunction with the Mongolian linguistic resources. Instead of treating 'share' as specifically English, it is better understood as Facebook technology's default linguistic features (e.g. 'like', 'share', 'comment' buttons), used by thousands, if not millions, of other Mongolian FB consumers (see also Dovchin, 2015, 2016a, 2016b). For instance, 'Share' is localized in three different ways in this short promotion:

- In line 1, FB technology feature 'Share' is used in its original form as 'Share'. This 'Share' is then followed by the Cyrillic Mongolian verb 'хийж' 〈'by doing'〉, creating the unconventionally mixed Mongolian term 'share хийж' meaning 'by $\langle$ doing $\rangle$ sharing'.

- In line 3, 'Share' is also combined with the Cyrillic Mongolian suffix to express the polite language 'лээрэй!'〈'please!'〉, producing the Mongolian term, 'share-лээрэй' 〈'Please share!'〉. 
- In lines 6 and 7, FB feature 'share' is mixed with the Cyrillic Mongolian phrase 'хийсэн хүмүүсийн' 〈'people who did'〉, creating a locally relevant linguistic meaning 'Share хийсэн хүмүүсийн' 〈'people who shared [on FB]'〉.

- In line 7, in a similar vein to 'share', another FB technology term 'profile', referring to 'FB profile' is Cyrillically Mongolianized through the combination with the Mongolian postpositional suffix '-aac' ' 'from'〉, constructing the new local linguistic meaning of 'профайлаас' 〈'from profile'〉.

- In line 8, other tech related English stem terminology, 'Random Picker program' is totally localized by Cyrillically Mongolianizing the 'program' as 'програм' and the addition of the Mongolian postpositional suffix '-aap' 〈'by'〉. Consequently, the new Mongolian phrase, 'Random Picker програмаap' is created indicating the meaning of 'by Random Picker program'. Random Picker program is a technical term referring to a random winner generator application for any contests, lotteries or sweepstakes and will validate the correctness of one's draws. Overall, the technology related English root terms and phrases are used through the Anglicized Mongolianized versions rather than the equivalent Mongolian translations. Some English tech words are 'untranslatable' into Mongolian and translating these words may cause ludicrous results, and many locals try to avoid the efforts. Where there are no native terms for the concepts they convey, English quickly take root and grow locally.

\section{Conclusion}

Drawing on Facebook linguistic repertoires of Mongolian users, this article offers an important implication in understanding the role of English in modern Mongolia. It can be argued that the presence of English in the FB space of Mongolia is unquestionably popular as there is virtually no single FB page I have looked so far where English is nonexistent. From this initial look, we can easily gloss English as the universal or one-size-fits-all language for the majority of Mongolian FB pages. It has become clear that the majority of Mongolian FB domains have already allowed for the inclusion of English to further facilitate and expand their linguistic creativity.

However, the fact is that now, when we visit these Mongolian FB pages, English is predominantly meshed and mixed with the Mongolian language. It is incredibly hard to either determine or comprehend the sole meaning of English on these FB pages. English has become indecipherable to
English speakers when in contact with Mongolian. English is effortlessly integrated into the Cyrillic and transliterated Roman Mongolian scripts, full Mongolian sentences and the Mongolian grammatical, phonetic, lexical, and syntax systems. Rather than merely borrowing English for the Mongolian context, the Mongolian FB users relocalize English alongside Mongolian to function in the space of localization. It can no longer be considered as separate linguistic system but rather as part of local language. Mongolian FB users exploit the varied symbolic and stylistic meanings attached to English to accommodate their own communicative practices through localizing English oriented linguistic and cultural resources while generally maintaining the multiple layers of local meanings. Put simply, the speakers relocalize English linguistic resources associated with particular stylistic and sociolinguistic contexts into the new local spheres of language use in an effort to capitalize on the original stylistic and symbolic meanings. The relocalization of this combination of English and Mongolian expand the linguistic horizon of the new linguistic domains of local language. The combination of English and Mongolian further creates new locally relevant words, meanings, phrases and terms, enriching the modern Mongolian language.

\section{References}

Battles, H. 2010. 'Exploring ethical and methodological issues in internet based research with adolescents.' International Journal of Qualitative Methods, 9(1), 27-39.

Blommaert, J. 2010. The Sociolinguistics of Globalization. Cambridge: University Press.

Canagarajah, S. 2005. 'Dilemmas in planning English/ vernacular relations in post colonial communities.' Journal of Sociolinguistics, 9(3), 418-447.

Canagarajah, S. 2013. Translingual Practice: Global Englishes and Cosmopolitan Relations. New York: Routledge.

Cohen, R. 2005. 'English in Mongolia.' World Englishes, 24(2), 203-216.

Dovchin, S. 2011. 'Performing identity through language: The local practices of urban youth populations in post-socialist Mongolia.' Inner Asia, 13(2), 315-333.

Dovchin, S. 2015. 'Language, multiple authenticities and social media: The online language practices of university students in Mongolia.' Journal of Sociolinguistics, 19(4), 437-459.

Dovchin, S. 2016a. 'The ordinariness of youth linguascapes in Mongolia.' International Journal of Multilingualism. Online at $<$ http://www.tandfonline.com/doi/full/10.1080/ 14790718.2016.1155592> (Accessed April 15, 2016).

Dovchin, S. 2016b. 'The translocal English in the linguascape of popular music in Mongolia.' World Englishes. Online at $<$ http://onlinelibrary.wiley.com/doi/ 10.1111/weng.12189/full> (Accessed May 18, 2016). 
Dovchin, S., Sultana, S., \& Pennycook, A. 2015.

'Relocalizing the translingual practices of young adults in Mongolia and Bangladesh.' Translation and

Translanguaging in Multilingual Contexts, 1(1), 4-26.

Dovchin, S., Sultana, S., \& Pennycook, A. 2016. 'Unequal translingual Englishes in the Asian peripheries.' Asian Englishes. Online at $<\mathrm{http}: / / \mathrm{dx}$.doi.org/10.1080/13488678. 2016.1171673> (Accessed May 27, 2016).

Gardner-Chloros, P. 2009. Code-switching. Cambridge: University Press.

Higgins, C. 2009. English as a Local Language: Post-colonial Identities and Multilingual Practices. Bristol: Multilingual Matters.

Internet World Statistics. 2016. 'Mongolia.' Online at $<$ http:// www.internetworldstats.com/asia.htm\#mn> (Accessed April 28, 2016).

Jørgensen, J. N. 2008. 'Polylingual languaging around and among children and adolescents.' International Journal of Multilingualism, 5(3), 161-176.

Jørgensen, J. N., Karrebæk, M. S., Madsen, L. M., \& Møller, J. S. 2011. 'Polylanguaging in Superdiversity.' Diversities, 13(2), 23-38.

Khorkhoi Odnoo Kitchen. 2015. 'Chef.' Online at $<$ https:// www.facebook.com/pages/Khorkhoi-Odnoo> (Accessed July 20, 2015).

Kinood. 2015. 'Film.' Online at $<$ https://www.facebook. com/kinood?fref $=$ ts $>$ (Accessed August 18, 2015).

Kozinets, R. 2002. 'The field behind the screen: Using netnography for marketing research in online communities.' Journal of Marketing Research, 39(1), 61-72.

Kozinets, R. 2015. 'Netnography.' The International Encyclopedia of Digital Communication and Society, 1-8.

Leppänen, S., Pitkänen-Huhta, A., Piirainen-Marsh, A., Nikula, T., \& Peuronen, S. 2009. 'Young people's translocal new media uses: A multiperspective analysis of language choice and heteroglossia.' Journal of ComputerMediated Communication, 14(4), 1080-1107.
Marsh, P. 2010. 'Our generation is opening its eyes: Hip-hop and youth identity in contemporary Mongolia.' Central Asian Survey, 29(3), 345-358.

McCorkindale, T. 2010. 'Can you see the writing on my wall? A content analysis of the Fortune 50's Facebook social networking sites.' Public Relations Journal, 4(3), 1-14.

Mongolian Ski Association. 2015. 'Sports Venue \& Stadium.' Online at <https://www.facebook.com/pages/ Mongolian-SkiAssociation/623785151069625?fref=ts $>$ (Accessed August 1, 2015).

Myers-Scotton, C. 2006. Multiple voices: An Introduction to Bilingualism. Malden, MA: Blackwell.

Otsuji, E. \& Pennycook, A. 2010. 'Metrolingualism: Fixity, fluidity and language in flux.' International Journal of Multilingualism, 7(3), 240-254.

Pennycook, A. 2010. Language as a Local Practice. London: Routledge.

Poplack, S. 2001. 'Code-switching.' International Encyclopedia of the Social and Behavioral Sciences, 2062-2065.

Preisler, B. 1999. 'Functions and forms of English in a European EFL country.' In T. Bex \& R. J. Watts (eds.), Standard English: The Widening Debate. London: Routledge, pp. 239-267.

Schneider, E. W. 2007. Postcolonial English: Varieties Around the World. Cambridge: University Press.

Sultana, S., Dovchin, S., \& Pennycook, A. 2013. 'Styling the periphery: Linguistic and cultural takeup in Bangladesh and Mongolia.' Journal of Sociolinguistics, 17(5), 687-710.

Sultana, S., Dovchin, S., \& Pennycook, A. 2015. 'Transglossic language practices of young adults in Bangladesh and Mongolia.' International Journal of Multilingualism, 12(1), 93-108.

Тунгалаг дурангийн дэлгүур 〈'The Shop of transparent lens' $\rangle$. 2015. 'Shopping \& Retail.' Online at $<$ https:// www.facebook.com/Tungalag.scope?fref $=$ photo $>$ (Accessed May 30, 2015). 